\title{
ISTIQOMAH DALAM BELAJAR (Studi atas Kitab Ta'lim Wa Muta'allim)
}

Oleh :

Makhromi $^{*}$

\section{Abstraks :}

Kajian ini adalah kajian kepustakaan mengenai konsep Istiqomah dalam belajar menurut perspektif Kitab Ta'lim Wa Muta'allim. Dalam Ta'lim, belajar adalah kemampuan belajar dan keinginan yang tinggi untuk mengetahui segala ilmu pengetahuan. Untuk mencapai kemuliaan dan keutamaan sebuah ilmu yang dicitacitakan itu, kitab Ta'lim menganjurkan bagi seorang pelajar untuk selalu menggunakan kesempatan dan waktunya untuk belajar terus menerus (Istiqomah).

Sebagaimana hasil kajian, faktor yang mampu melahirkan istiqamah dalam jiwa seseorang menurut Ta'lim adalah beramal dan melakukan optimalisasi, berlaku moderat antara tindakan melampaui batas dan menyia-nyaiakan, tidak melampaui batas yang telah digariskan ilmu pengetahuannya, tidak menyandarkan pada faktor temporer melainkan bersandar pada sesuatu yang jelas, dan ikhlas mengikuti sunnah. Dan kiat untuk meningkatkan Istqomah diantaranya ialah muraqabah, mu'ahadah, muhasabah, mu'aqabah, dan mujahadah (optimalisasi).

Kata Kunci : Istiqomah, Belajar, Ta'lim Wa Muta'allim

\section{Pendahuluan}

Problem besar bangsa Indonesia dalam pergaulan global terletak pada lemahnya sumberdaya manusia. Kekayaan alam yang demikian melimpah, posisi geografis yang menguntungkan karena diapit oleh dua benua serta dua lautan besar, serta jumlah penduduk yang menempati urutan ke empat dunia, sangat terasa tidak diimbangi oleh kualitas sumberdaya manusia Indonesia. Kualitas yang tidak memadai bagi kepentingan mendayagunakan sejumlah keunggulan yang dimiliki Indonesia inilah yang menjadikan bangsa ini tidak cukup berkekuatan dalam persaingan global.

Secara ekonomi negara ini tergolong beasar karena kandungan kekayaan alamnya yang melimpahruah. Secara politis juga besar karena

\footnotetext{
* IAI Tribakti Kediri.
} 
Indonesia merupakan negara muslim terbesar dengan sistem demokrasi. Tetapi ternyata sejumlah predikat 'besar' yang dimilki oleh Indonesia terkait dengan posisi potensialnya tidak begitu mudah diaktualisasikan. Saat ini, posisi geografis yang semestinya dapat menguntungkan Indonesia ternyata hal itu dinikmati oleh Singapura. Secara demografis Indonesia ini besar, namun yang untung Cina dan Jepang serta Korea karena merupakan pasar bagi produk mereka karena produk Indonesia tak mampu bersaing dengan mereka. Kekyaan alam melimpah, yang menikmati juga Amerika dan Eropa karena mereka yang memiliki hak pengelolaan sampai puluhan tahun. Sebagai negara muslim terbesar juga tidak cukup berarti bagi dunia karena dialog antara agama seringnya justru bukan diprakarsai oleh Indonesia, tetapi kaum fundamentalis Arab yang sangat Wahabiyah.

Sebagaimana yang telah diurai di atas, secara jelas memberi gambaran tentang belum memadainya kualitas sumberdaya manusia Indonesia untuk menjadikan segala kekuatan potensialnya menjadi sesuatu yang secara nyata bermanfaat bagi bangsa yang besar ini. Terkait dengan hal ini, kata kunci bagi peningkatan kualitas sumberdaya manusia adalah pendidikan. Artinya, kemajuan setiap bangsa yang ditandai oleh baiknya kualitas sumberdaya manusia, sangatlah tergantung kepada kemauan atau niat serta arah kebijakan pemerintah dalam bidang pendidikan dan juga respons masyarakat terhadap niat pemerintah tersebut.

Konsep belajar pada saat ini lebih memberi peluang bagi munculnya kreativitas peserta didik dibandingkan sebagaimana yang terjadi pada masa dahulu yang memberi penjelasan adanya pusat orientasi kepada pengajarnya. Pengajar pada saat ini lebih berposisi fasilitator bagi proses transformasi ilmu pengetahuan. Sementara itu, peserta didik harus secara aktif menggali dan kemudian memahami pengetahuan yang dikehendaki sesuai dengan spesifikasi keilmuannya. Dengan demikian, maka keberhasilan suatu proses belajar lebih terletak pada hasrat peserta didik dalam mengelola niat memperoleh pengetahuan. Pengelolaan niat belajar dan memelihara tindakan yang diorientasikan kepada perolehan ilmu pengetahuan sangat mempengaruhi keberhasilan proses belajar.

Terkait dengan proses belajar yang intensif, dalam Islam terdapat konsep Istiqomah. Secara garis besar, konsep ini merekomendasikan suatu proses belajar yang bertumpu pada komitmen dalam membangun kepribadian sesuai doktrin Islam. Sebagai negara dengan jumlah penduduk muslim terbesar di dunia, wajarlah bagi pemerintah Indonesia untuk membangun 
kualitas sumberdaya manusianya dengan mengedepankan konsep Istiqomah. Kesesuaian kulturistik keIslaman tentu akan menyumbang percepatan bagi terwujudnya kualitas manusia Indonesia yang memadai bagi kepentingan menjadiakan segala potensi bangsa yang ada untuk memperkuat daya saing global. Praduga inilah yang akhirnya menuntun peneliti menetapkan topik penelitian terkait syarat perolehan gelar kesarjanaan dengan judul 'Konsep Istiqomah dalam Belajar' yakni suatu studi kepustakaan tentang Konsep Istiqomah dalam Perspektif Ta'lim Wa Muta'allim.

\section{Istiqomah Secara Umum}

\section{Pengertian Istiqomah}

Bentuk lafad Istiqomah yang diambilkan dari fi'il madhi istaqoma secara bahasa mengandung arti berusaha berdiri secara tegap. Hal ini tidak lepas dari asal katanya yaitu lafad qoma .sedang perubahan dari qoma menuju Istiqomah hanyalah bentuk ikutan pada wajan istaf'alan yang masdar simaiinya istif'alan. ta marbuthoh pada lafad istaqoma merupakan bawaan dari keumuman /simaa'i orang arab ketika melafadkan Istiqomah ${ }^{1}$

Istiqamah berarti berdiri tegak lurus (dalam Kamus Besar Bahasa Indonesia), istiqamah diartikan sebagai sikap teguh pendirian dan selalu konsekuen. Jelasnya istiqomah bisa diartikan senantiasa sabar dalam menghadapi seluruh godaan dalam medan yang diembaseseorang. Meskipun tahapan tokoh sentralnya mengalami perubahan. Itulah manusia muslim sesungguhnya, selalu istiqamah dalam sepanjang jalan dan di seluruh tahapan. Hal ini sebagaimana tersurat dalam QS. Al-Ahqof ayat 13-14. ${ }^{2}$

Sedangkan secara secara terminologi, Istiqomah bisa diartikan dengan beberapa pengertian berikut ini;

a. Abu Bakar As-Shiddiq ra ketika ditanya tentang Istiqomah ia menjawab; bahwa Istiqomah adalah kemurnian tauhid (tidak boleh menyekutukan Allah dengan apa dan siapapun) ${ }^{3}$

b. Umar bin Khattab ra berkata: "Istiqomah adalah komitmen terhadap perintah dan larangan dan tidak boleh menipu sebagaimana tipuan musang"

\footnotetext{
${ }^{1}$ Ali maksum Amtsilah Attasrifiyah (jombang, tt ) hlm 31

2 Fadh ibn 'Abd al- 'Aziz Al Sa'ud, AlQur'an dan Tejemahnya (Khadim Al-Haromain As-Syarifain), 824

${ }^{3}$ Utsman bin Hasan Ahmad Syakir Al-Khoubawi, Durrotun Nashikhin Fil Wa'dzi Wal Irsyad” (Bandung Idonesia), 199-200
} 
c. Utsman bin Affan ra berkata: "Istiqomah adalah mengikhlaskan amal kepada Allah swt"

d. Ali bin $A b u$ Thalib ra berkata: "Istiqomah adalah melaksanakan kewajiban-kewajiban"

e. Al-Hasan berkata: "Istiqomah adalah melakukan ketaatan dan menjauhi kemaksitan" 4

f. Mujahid berkata: "Istiqomah adalah komitmen terhadap syahadat tauhid sampai bertemu dengan Allah swt"

g. Ibnu Taimiah berkata: "Mereka berIstiqomah dalam mencintai dan beribadah kepadaNya tanpa menengok kiri kanan"5

Dari beberapa definisi di atas, jika dikaitkan dengan belajar, maka bisa disimpukan bahwa yang dimaksud dengan Istiqomah adalah selalu tepat waktu, menggunakan waktu sebaik-baiknya, konsekuen, teguh dan gigih dalam belajar, mematuhi peraturan sekolah, guru, dan menjahui laranganlarangan sekolah.

\section{Karakteristik Pribadi yang Istiqomah}

Untuk Mengenal Karakter-karakter Pribadi Muslim yang Istiqomah ${ }^{6}$ pertama perlu mengetahui Apa sebenarnya yang dimaksud dengan istiqamah? Dari hadist dan pendapat-pendapat yang membahas Istiqomah, bisa ditarik kesimpulan Karakterstik Pribadi yang Istiqomah memang erat kaitannya dengan keteguhan untuk selalu berada di jalan lurus yang luas atau berbuat mendekati jalan lurus yaitu disekitar Garis Keseimbangan Optimum dengan ketulus ikhlasan semata-mata karena ridha Allah. Akan tetapi, kendati hal ini dapat dilakukan dengan berbuat amal, namun ternyata kuantitas (banyak sedikitnya) amal ini tidak menjamin bahwa manusia akan berada di Shiraatal Mustaqiim dan selamat di hari akhir, kecuali adanya limpahan rahmat dan karunia Allah SWT. Jadi, keberadaan kita di jalan lurus dengan keistiqamahan sebenarnya berkaitan erat dengan Kehendak Allah SWT bukan akibat perbuatan kita atau amal kita semata. Kembali kita akan temui bahwa ridha Allah menjadi sebab utama dari keistiqamahan seorang hamba sebagai suatu limpahan karunia dan rahmat-Nya. Dan keridhaan Allah tersalur melalui Asma-asma Allah dan bukan dari usaha seorang hamba semata.

\footnotetext{
${ }^{4}$ Ibid, $199-200$

5 Ibid, 199-200

${ }^{6}$ pojokbangbens.blogspot.com/2007/09/waduh.html
} 
Menurut pendapat Ibnu Qayyim Al-Jauziya, istiqamah merupakan kalimat yang mengandung banyak makna, meliputi berbagai sisi agama, yaitu berdiri di hadapan Allah secara hakiki dan memenuhi janji. Istiqamah karena itu berkaitan dengan akhlak dan perilaku berupa perkataan, perbuatan, keadaan, dan niat. Istiqamah dalam hal ini berarti pelaksanaannya karena Allah, beserta Allah, dan berdasarkan perintah Allah.

Dalam banyak aspek, istiqamah merupakan suatu ruh atau energi spiritual yang karenanya keadaan menjadi hidup dan juga menyuburkan amal manusia secara umum. Oleh karena semua amal tergantung niatnya, dan niat erat kaitannya dengan keikhlasan dan ridha Allah semata, maka istiqamah dalam banyak aspek akan berkaitan dengan kontinuitas atau konsistensi untuk selalu berada di Shiraathal Mustaqiim dengan pengolahan jiwa atau nafs manusia atau penyucian jiwa.

Istiqamah menyembunyikan kekeramatan. kekeramatan yang pertama tentang Iman. Yang kedua adalah penyaksian. Iman dan penyaksian adalah penauhidan atas keesaan-Nya Maka, istiqamah adalah bekal utama bagi yang melakoni jalan apapun termasuk di dalamnya adalah belajar. Dari uraian di atas, bisa ditarik kesimpulan bahwa karakteristik orang yang Istiqomah kalau dikaitkan dengan belajar adalah menjalankan aktivitas belajar atau menuntut ilmu bukan dengan alasan untuk saling menjatuhkan, dan untuk kesombongan diri melainklan limpahan rahmat Tuhan. Hanya saja yang perlu menjadi catatan adalah tetap melakukan aktivitas belajar.

\section{Faktor Munculnya Istiqomah}

Ibnu Qayyim dalam "Madaarijus salikin" menjelaskan bahwa ada enam faktor ynag mampu melahirkan istiqamah dalam jiwa seseorang, yaitu: beramal dan melakukan optimalisasi (QS. Al-Hajj : 78); berlaku moderat antara tindakan melampaui batas dan menyia-nyaiakan (QS. Al-Furqon : 67); dan tidak melampaui batas yang telah digariskan ilmu pengetahuannya (QS. Al-Isra' : 36). ${ }^{7}$

\section{Dampak Positif Istiqomah}

Manusia muslim khususnya orang yang menuntut ilmu pengetahuan yang beristiqamah dan selalu berkomitmen dengan nilai-nilai kebenaran Islam dalam seluruh aspek hidupnya akan merasakan dampak yang positif dan buah yang lezat sepanjang hidupnya. Adapun dampak dan buah

\footnotetext{
${ }^{7}$ gunawan-wibisono-.blogspot.com/2008/02/istiqamah.html
} 
istiqamah sebagai berikut: keberanian (Syaja'ah); ketenangan (Ithmi'nan) (QS. 13:28); dan optimis (tidak putus asa), (QS. 12:87). ${ }^{8}$

Orang-orang yang berjiwa istiqamah akan sentiasa berbuat kebajikan, nasihat-menasihati dan tidak mudah berputus asa serta sabar dalam melaksanakan ibadah dan belajar. Diantara faktor yang dapat membantu kita untuk mencapai sikap istiqamah ialah: pertama, Mujahadah, yaitu mengarahkan hati untuk berjuang melawan tuntunan nafsu dan sifat malas yang merangsang ke arah kejahatan dan malas belajar. Di samping itu, keinginan nafsu, sifat malas serta kehendak-kehendak duniawi wajarlah dibimbing sehingga ia menjurus ke arah kebaikan dan keikhlasan kerana Allah semata. Memang tidak dinafikan, mujahadah melawan hawa nafsu dan sifat malas itu tidak mudah. Mereka adalah sesuatu yang menjalar dan perlu ditaklukan, guna mencapai kesuksesan dunia-akhirat. Segala kesulitan dalam bermujahadah melawan hawa nafsu dan sifat malas adalah ujian yang perlu ditangani dengan bersungguh-sungguh, sabar serta tawakal kepada Allah Swt.

Istiqomah merupakan keperluan asasi dalam segenap ibadah dan menuntut ilmu, kerana ia adalah bukti ketaatan serta kecintaan seorang hamba kepada penciptanya. Meskipun ibadah atau belajar yang kita lakukan itu kecil, tetapi jika dilaksanakan secara istiqamah maka ia lebih disukai oleh Allah dibandingkan ibadah dan belajar yang besar tetapi tidak disertai dengan sikap istiqamah.

\section{Pentingnya Istiqomah}

Setiap muslim yg telah berikrar bahwa Allah Rabbnya, Islam agamanya, Muhammad rasulnya, harus senantiasa memahami ikrar ini dan mampu merealisasikan nilai-nilainya dalam kehidupannya. Setiap dimensi kehidupannya harus terwarnai dengan nilai-nilai tersebut, baik dalam kondisi aman maupun terancam

Namun dalam realitas kehidupan dan fenomena umat, kita menyadari bahwa setiap orang yang memiliki pemahaman yang baik tentang Islam mampu mengimplementasikan dalam seluruh sisi kehidupannya. Dan orang yang mampu mengimplementasikannya belum bisa bertahan sesuai dengan yang diharapkan Islam, yaitu komitmen dan istiqamah dalam memegang ajarannya sepanjang perjalanan hidup ${ }^{9}$

\footnotetext{
${ }^{8}$ gunawan-wibisono-.blogspot.com/2008/02/istiqamah.html ,

9 gunawan-wibisono-.blogspot.com/2008/02/istiqamah.html
} 
Maka istiqamah dalam memegang tali Islam meupakan kewajiban asasi dan sebuah keniscayaan bagi hamba-hamba Allah yang menginginkan khusnul khatimah dalam kesuksesan.

Istiqamah bukan hanya diperintahkan kepada manusia biasa saja, tapi juga bagi manusia besar, seperti para nabi dan rasul. Perhatikan QS. Al-Hud ayat $112 .{ }^{10}$ Dalam ayat ini menggambarkan urgensi istiqamah setelah beriman dan pahala besar yang dijanjikan Allah SWT, seperti hilangnya rasa takut, sirnanya kesedihan dan surga bagi hamba-hamba Allah yang senantiasa memperjuangkan nilai-nilai keimanan dalam setiap kondisi dan situasi apapun. Selain ayat-ayat diatas, ada beberapa pernyataan ulama tentang urgensi istiqamah.

Istiqmah lebih baik dari seribu karomah.Dengan istiqmah secara konsis lambat laun akan mendapatkan hasil yang dituai,karena dengan keuletan yang proporsional kita berusaha menaklukan realitas eksternal kita, saat tujuan kita telah tercapai disitulah letak keistimewaan (karomah) yang dihasilkan dari upaya jerih payah kita

Dari uaraian di atas bisa ditarik kesimpulan bahwa iastiqomah sangatlah penting dalam segala hal, khususnya dalam penelitian kami yaitu Istiqomah dalam belajar, karena banyak nilai positif yang tersimpan dari Istiqomah yang telah dijelaskan dalam dampak positif Istiqomah.

\section{Pengertian Belajar}

Belajar merupakan salah satu faktor yang mempengaruhi dan berperan penting dalam pembentukan pribadi dan perilaku individu. تَعَّْ merupakan bentuk masdar ghoiru mim dari fi'il madli نَعَ yang mempunyai faidah takalluf (berusaha secara maksimal) yang sehingga bisa diartikan dengan berusaha semaksimal mungkin memahami ilmu.

Di bawah ini disampaikan tentang pengertian belajar dari para ahli :

a. Moh. Surya: "belajar dapat diartikan sebagai suatu proses yang dilakukan oleh individu untuk memperoleh perubahan perilaku baru secara keseluruhan, sebagai hasil dari pengalaman individu itu sendiri dalam berinteraksi dengan lingkungannya".

b. Witherington : "belajar merupakan perubahan dalam kepribadian yang dimanifestasikan sebagai pola-pola respons yang baru berbentuk keterampilan, sikap, kebiasaan, pengetahuan dan kecakapan".

${ }^{10}$ Fadh ibn 'Abd al- 'Aziz Al Sa'ud, AlQur'an dan Tejemahnya (Khadim Al-Haromain As-Syarifain), 344 
c. Crow \& Crow : “ belajar adalah diperolehnya kebiasaan-kebiasaan, pengetahuan dan sikap baru".

d. Hilgard : "belajar adalah proses dimana suatu perilaku muncul perilaku muncul atau berubah karena adanya respons terhadap sesuatu situasi"

e. Di Vesta dan Thompson: “ belajar adalah perubahan perilaku yang relatif menetap sebagai hasil dari pengalaman".

f. Gage \& Berliner : "belajar adalah suatu proses perubahan perilaku yang yang muncul karena pengalaman"

Dari beberapa pengertian belajar tersebut diatas, kata kunci dari belajar adalah perubahan perilaku. Dan ilmu pengetahuan bisa diperoleh dengan adanya belajar secara Istiqomah, dan kemampuan belajar, keinginan yang tinggi, kesabaran, dan hal-hal lain yang erat kaitannya dengan keberlangsungan proses belajar atau mencari ilmu pengetahuan. ${ }^{12} \mathrm{Hal}$ ini sesuai dengan apa yang diungkapkan oleh Syekh Al-Zarnuji "ingatlah..... Ilmu tidaklah mungkin diperoleh kecuali dengan enam hal, kemampuan belajar (Cerdas), keinginan yang tinggi, sabar, biaya, petunjuk guru, waktu yang lama"13

\section{Manajemen Waktu}

Waktu, adalah dimensi yang tak terulang dan tak tergantikan. Apa yang istimewa dengan waktu sehingga Allah Swt. sampai bersumpah dengannya, bahkan di pembukaan beberapa surat yang lain seperti: wa dhuhaa, wal laili.., wal fajr. Tidak dipungkiri bahwa kalau Allah Swt. sampai bersumpah dengan nama makhluknya menunjukkan betapa penting hal itu untuk diperhatikan oleh makhuk-Nya. Bila dimengerti lebih lanjut Al Qur'an juga menyebutkan mengenai penggalan-penggalan waktu, seperti disebutkan dalam surat Ali Imron: 190. Ayat tersebut mengabarkan bahwa Allah menciptakan pergantian malam dan siang dimana didalamnya banyak pelajaran dan hikmah yang bisa diambil oleh orang-orang yang berakal. dari rahasia waktu yang telah diciptakanNya untuk bisa dimanfaatkan oleh manusia sebaik-baiknya, dan apa rahasia umur yang diberikanNya. Apa yang akan diuraikan adalah mengacu pada Al Qur'an, hadits, kitab-kitab yang

${ }^{11} \mathrm{http} /$ /husniabdillah. Multiplay.com/jurnal/pengertian belajar tgl 19 Juli 2009 jam 20:42

${ }_{12}^{12}$ Syekh Azzarnuji, Ta'lim Wa Muta'allim, (Surabaya: Haromain), 15

${ }^{13}$ Ibid, hlm 23 
telah disusun oleh para ulama ahli hadits dan ahli tafsir serta para praktisi management waktu. intisari dari acuan tersebut dan mengungkap pengalaman dan perenungan dari beberapa peristiwa sebagai upaya untuk lebih mengendapkan hikmah ke dalam sanubari. Mengapa penulis mengawali dengan membahas awal waktu? Hal yang diharapkan adalah, dengan mengerahkan segenap kesabaran memahami hal-hal yang tersebut di awal, kita akan memenangkan sesuatu di awal, selanjutnya kemenangan berikut akan mengalir seperti air dengan keoptimisan yang telah diraih. Yang lebih penting juga adalah kata-kata dan tulisan yang mengalir menghidupkan hati dan menumbuhkan optimisme tidak akan berarti kecuali perasaan itu bisa kita kelola dengan tepat dan mampu untuk menggerakkan diri menuju suatu amal perbuatan nyata. $^{14}$

Orang-orang Barat sering dikatakan adalah orang-orang yang menghargai waktu, apapun alasan dan motivasinya. Jika kita lihat dalam acara TV banyak para pria dan wanita keluar di waktu pagi, mereka diantaranya ada yang memang harus segera ke tempat kerja, jalan-jalan pagi sambil menuntun anjingnya, ada juga petugas sampah dengan mobilnya di pagi buta menyelesaikan tugas sebelum orang-orang lain mulai beraktifitas. Ada anak-anak kecil dan remaja, mereka keluar pagi-pagi untuk bekerja mengantar koran. Mereka tampak sungguh-sungguh mengawali waktu di pagi hari, seolah mereka tidak ingat bahwa kondisi cuaca dingin, lupa akan hangatnya kasur dan selimut yang mendorong mereka berlama-lama di kamar tidur. Entah apa sesungguhnya yang menggerakkan dirinya, apakah sekedar menyenangkan anjingnya atau sekedar mendapatkan upah loper koran. Tetapi yang pasti mereka segera bergegas keluar rumah memaksakan diri dan mengatasi segala perasaan yang memberatkan. Sekali lagi apapun motivasinya yang jelas sadar atau tidak mereka telah memenangi satu pertarungan melawan perasaan. Mereka mengawali hari mereka dengan suatu kemenangan. Mereka mampu mengatasi suatu hambatan.

Memang tidak ada satu cara yang ampuh yang berlaku bagi semua orang dalam manajemen waktu, tetapi dengan mengenali diri sendiri dengan lebih baik kita dapat menentukan bagaimana kita akan mempergunakan waktu kita dengan lebih efektif. Patut pula diingat bahwa inti dari manajemen waktu adalah konsentrasi pada hasil dan bukan sekedar menyibukkan diri.

\footnotetext{
${ }^{14}$ http://www.hikmah-soleh.blogspot.com/Sukses Meraih Kemenangan Sepanjang Waktu
} 
Banyak orang menghabiskan hari-harinya dengan berbagai kegiatan yang seakan tiada habisnya tetapi tidak mendapat capaian apapun karena kurang konsentrasi pada hal yang benar.

Salah satu sistem manajemen waktu yang bisa dipilih oleh mahasiswa adalah menggunakan sistem siklus pada setiap tahun ajaran atau setiap semester. Umumnya sistem ini dimulai dengan menetapkan tujuan (goal setting) untuk mengukuhkan konteks bagi manajemen waktu. Berikutnya adalah menelusuri penggunaan waktu dan membangun kesadaran tentang bagaimana akan menghabiskan waktu. Tahap ketiga adalah membuat rencana, dan ini termasuk membuat to do list, rencana mingguan, rencana bulanan, dan rencana semesteran. Tahap keempat adalah memantau (self monitoring) apa yang telah dikerjakan. Pada tahap ini menilai seberapa baik menjalankan rencana, seberapa akurat membuat rencana, seberapa tepat menduga kegiatan-kegiatan yang dilakukan, dan sebagainya. Tahap akhir dari siklus manajemen waktu ini adalah pergeseran dan penyesuaian waktu dimana kita melakukan koreksi terhadap sistem yang berjalan sebelum memulai siklus yang baru.

\section{Konsep Istiqomah dalam Kitab Ta'lim Muta'alim \\ Selayang Pandang Kitab Ta'lim Wa Muta'alim}

Berdasarkan pengamatan penulis, al-Zarnuji dalam menulis karyanya (Ta'lim al-Muta'allim) sangat kronologis. Beliau memulai dengan bacaan basmalah, kemudian memuji kepada Alloh SWT, Tuhan yang telah melebihkan manusia dengan ilmu dan amal atas semesta alam, Sholawat semoga tetap terlimpah ke haribaan Muhammad, penghulu/ tokoh Arab dan 'Ajam, lalu keluarga dan sahabat-sahabat beliau yang merupakan sumber pengetahuan dan hikmah. Al-Zarnuji kemudian mengemukakan alasan beliau menulis kitab Ta'lim al-Muta'allim yaitu banyak penuntut ilmu di zamannya yang tekun tetapi tidak bisa memetik kemanfaatan dan buahnya, yakni mengamalkan dan menyiarkannya. Lantaran mereka salah jalan dan meninggalkan syarat-syaratnya, padahal sesuatu yang salah jalan itu akan tersesat dan gagal tujuannya. Alasan ini diambil dari kitab guru beliau yang alim dan arif.

Kitab Ta'lim al-Muta'allim terbagi kedalam tiga belas fasal dengan perincian sebagai berikut : Fasal 1. Pengertian ilmu, fiqih dan keutamaannya; Fasal 2. Tentang niat belajar; Fasal 3. Tentang memilih guru, teman dan mengenai ketabahan; Fasal 4. Menghormati ilmu dan ulama'; Fasal 5. 
Sungguh-sungguh, kontinuitas dan antusias; Fasal 6. Permulaan, ukuran dan tata tertib belajar; Fasal 7. Tawakkal; Fasal 8. Saat terbaik untk belajar; Fasal 9. Kasih sayang dan nasihat; Fasal 10. Istifadlah (mengambil pelajaran); Fasal 11. Wara' dikala belajar; Fasal 12. Penyebab hafal dan lupa; Fasal 13. Hal-hal yang menyebabkan bertambah atau berkurangnya rizqi dan umur. Dan yang menjadi fokus peneliti adalah pada fasal 5, khusunya pada kontinuitas dalam belajar.

\section{Konsep Istiqomah dalam Ta'lim}

Konsep Istiqomah dalam ta'lim bisa diartikan dengan: pelajar hendaknya sanggup belajar dan mengulangi pelajaran secara kontinyu pada awal waktu malam dan di akhir waktu malam. Sebab antara waktu dari maghrib sampai isya, serta waktu sahur adalah membawa berkah.

Penuntut ilmu jangan sampai membuat dirinya kelelahan, sehingga lemah dan tidak dapat berbuat sesuatu, sabda Rosululloh SAW, "Ingatlah bahwa agama ini (Islam) adalah agama yang kokoh, santunilah dirimu dalam menunaikan tugas agama, janganlah kau buat diimu sengsara lantaran ibadahmu kepada Allah. Sesungguhnya orang yang telah hilang kekuatannya tidak akan bisa meneruskan perjalanan dan menunggangi kendaraannya. Lebih lanjut beliau bersabda, "Ilmu adalah kendaraanmu, maka santunilah.

Pelajar dan Mahasiswa hendaknya bersungguh-sungguh dan memikirkan secara mendalam apa yang diterima dari guru, serta mengulanginya. Apabila ia meremehkan satu kali, dua kali hingga menjadi kebiasaannya, maka ia tidak akan bisa memahami sesuatu sekalipun gampang. Penuntut ilmu hendaknya dapat memperhitungkan berapa kali ia harus mengulangi pelajaran dan ia tidak akan tenang sebelum terpenuhinya target tersebut. Seyogyanya pelajaran kemarin diulang lima kali, pelajaran lusa diulang empat kali, kemarin lusa tiga kali, pelajaran sebelumnya dua kali dan sebelumnya lagi satu kali. Cara yang demikian akan mempermudah hafal. Dalam belajar dan menghafal para santri atau pelajar, hendaknya tidak membiasakan dengan suara yang pelan (dalam hati) dan tidak terlalu keras, yang baik adalah yang sedang-sedang saja dan penuh semangat. Belajar hendaklah hafal dengan baik sebuah kitab fiqih yang yang baru saja diterimanya. Selain itu, jangan sampai belajarnya terputus, karena hal itu akan merupakan afat (yang sangat menyusahkan) baginya. 


\section{Analisa}

Analisa kami berkaitan dengan Istiqomah yang ada dalam Ta'lim Wa Muta'allim yang diartikan dengan belajar pada waktunya (mengulangi pada waktu yang sama), bisa diartikan secara luas, mencakup tepat waktu dalam kegiatan belajar mengajar, bisa mengatur waktu sebaik mungkin, dan bisa memilih guru yang berkualitas serta materi pelajaran yang berbobot.

Dari uraian mengenai permulaan belajar, ukuran belajar, dan tata caranya, kami mencoba menganalisis bahwa: hari mulai belajar dalam menentukan permulaan hari untuk belajar, di Indonesia ada silang pendapat yang ditetapkan oleh pemerintah dan kaum agamawan. Adapun sistem yang ditetapkan oleh pemerintah adalah mewarisi sistem Kolonial Belanda, yaitu hari Senin sebagai hari permulaan belajar dan hari Ahad sebagai libur nasional. Karena pada hari itu orang-orang Belanda yang mayoritas beragama Kristen melakukan ibadah di gereja. Sedangkan kaum agamawan lebih mengutamakan tentang dasar yang bersumber pada hadits di atas, yaitu hari Rabu sebagai permulaan belajar. Ini berlaku di pesantren-pesantren salaf, seperti Pondok Pesantren Lirboyo Kediri, pesantern Al-Hidayah Lasem dan Pondok Pesantren Al-Hidayah Demak serta pondok-pondok salaf yang lain yang masih menggunakan sistem sorogan. Panjang pendeknya pelajaran dalam konsep Az-Zarnuji dapat dipahami dan dimaknai sebagai ukuran kemampuan belajar sang pelajar dalam mencapai sebuah ilmu dan agar ilmu yang telah didapat tidak hilang begitu saja ketika menambah ilmu baru. Tingkat pelajaran yang didahulukan dalam hal ini, kami sependapat dengan konsep Az-Zarnuji mengenai tingkat pelajaran yang didahulukan dan pemilihan kitab yang ringkas/kecil. Karena konsep tersebut sangat efektif untuk mendorong peserta didik pada proses pembelajaran. Membuat catatan kami sependapat dengan konsep Az-Zarnuji mengenai membuat catatan pelajaran-pelajaran yang telah dipahami kemudian diulang-ulang. Karena apabila ilmu yang telah kita pahami dan kita hafalkan tidak dicatat, tidak menutup kemungkinan suatu saat akan mudah lupa atau hilang. Dan untuk mengantisipasi hal tersebut, catatan sangat penting. Usaha memahami pelajaran diupayakan dalam memahami pelajaran dengan mencurahkan segala kemampuan, tidak hanya sebatas mendengarkan saja tapi harus benarbenar paham dan hafal. Sedangkan mengenai mudzakarah, munadharah, musyawaroh dan seterusnya sampai poin panik dan bingung, kami sepakat dengan konsep Az-Zarnuji. Karena kami rasa konsep tersebut masih relevan dengan kondisi sekarang. 
Kesimpulan dari konsep Az-Zarnuji mengenai hari mulai belajar ini masih sesuai dengan konteks pembelajaran yang dilaksanakan di pesantrenpesantren salaf, meskipun dalam pendidikan nasional sudah tidak menggunakan system ini. Bagi orang yang baru memulai belajar dianjurkan mengambil pelajaran yang kira-kira mampu untuk dipaham dan dihafalnya. membuat catatan mengenai pelajaran-pelajaran yang telah dipahami dan dihafalnya itu adalah cara yang sangat efektif. Pelajar harus memahami pelajaran dan mengulanginya serta tidak mengabaikannya. Disamping berusaha dengan sungguh-sungguh, pelajar juga harus selalu berdoa, bersyukur, selalu mengorbankan harta demi ilmu, dan lillahi ta'ala.

\section{Kesimpulan}

Kajian di atas bisa disimpulkan bahwa:

1. Konsep Istiqomah dalam ta'lim bisa diartikan dengan sanggup belajar dan mengulangi pelajaran secara kontinue pada awal waktu malam dan di akhir waktu malam. Dan menurut peneliti konsep Istiqomah dalam Ta'lim merupakan konsep belajar yang efektif dan bisa diterapakan dalam kegiatan belajar sehari-hari

2. Konsep Istiqomah Belajar dalam Ta'lim adalah kemampuan belajar dan keinginan yang tinggi untuk mengetahui segala ilmu continue sesuai dengan waktunya.

Selain iu, dalam kitab Ta'lim menganjurkan bagi seorang pelajar hendaknya selalu menggunakan kesempatan dan waktunya untuk belajar terus menerus sampai menghasilkan kemuliaan dan keutamaan sebuah ilmu yang dicita-citakan. Namun dalam hal ini, perlu adanya sistem dan manajemen yang baik untuk mencapai semua itu, mulai dari permulaan belajar, ukuran belajar, dan tata caranya. 


\section{DAFTAR PUSTAKA}

Fadh ibn 'Abd al- 'Aziz Al Sa'ud, AlQur'an dan Tejemahnya (Khadim AlHaromain As-Syarifain)

Ibnu Rusd, Hidayatul Mujtahid, (Libanon: Beirut, tt)

Imam Ghozal, Ihya' Ulumuddin, (Sulaiman Mara'I, Sangqopura Kuta Baharu Pinang:)

Imam Yahya Syarofuddin Annawawi Arbain Nawaw,(Almiftah Surabaya)

Jalaluddin Abdurrahman bin Abi Fakar As-Suyuthi, Jami'us Shoghir, (Darul Fikr)

Lexy J. Moleong, Metode Penelitian, (Pt Remaja Rosda Karya: 2007)

Maksum, Ali, Amtsilah Attasrifiyah, (Jombang,tt )

Noor, Fauz. Tapak Sabda, (Yogyakarta: LKIS, 2004)

Sayid Abi Bakar Al-Ma'ruf, Kifayatul At-Qiya' (Haromain, Surabaya)

Sutrisno Hadi, Metodologi Research (Yogyakarta: Yasbit, Fakultas Psikologi Universitas Gajahmada, $\mathrm{tt}$ ),

Syahatah,Husain, Kiat Islam Meraih Prestasi (Gema Insani, Jakarta 2004)

Syekh Azzarnuji, Ta'lim Wa Muta'allim, (Haromain, Surabaya:)

Syeikh Islam Muhyiddin Abi Zakariya bin Syarof An- Nawawi, Riyadlussholihin (Al-Haromain Surabaya)

Utsman bin Hasan Ahmad Syakir Al-Khoubawi, Durrotun Nashikhin Fil Wa'dzi Wal Irsyad" (Bandung Indonesia) 